\title{
ASSESSMENT OF MANAGEMENT CONTROLLING IN PANDEMIC TIMES
}

\author{
Matej Galić, PhD, Research Associate \\ The University of Applied Sciences Baltazar \\ Vladimira Novaka 23, Zaprešić, Croatia \\ mgalic@bak.hr
}

\section{Petra Popek Biškupec, PhD, Senior Lecturer \\ The University of Applied Sciences Baltazar \\ Vladimira Novaka 23, Zaprešić, Croatia \\ pbiskupec@bak.hr}

\author{
Marko Galić, MSc in Economics \\ Enna Properties d.o.o. \\ Gospodarska zona 13, Vukovar, Croatia \\ mgalic99@gmail.com
}

\begin{abstract}
The emergence of coronavirus led to evident consequences for the global economy. During the previous financial crisis, organisations have already determined the elements of crisis management so they could met the new corona crisis readily. Global changes, like the current pandemic situation, provide a different view toward the future expectations. The pandemic has caused new way of functioning under special circumstances such as various restrictions in many European countries, restrictions on people's mobility and other novelties that have encountered for the first time. Characteristics of this crisis include novelty and pressure in a business environment, which can reveal various vulnerabilities in organisations. Managers were affected by major business changes, and there appeared a need for rapid reorganisation of the current way of functioning. Management had to introduce new control systems that refer to their strategies for exchanging information and decision-making. In general, each crisis is a new opportunity for seeking modern and appropriate models and tools for business improvement. When business situations are challenging, managers are more oriented toward controlling. Therefore, organisations that focus on traditional management models are not very successful in normal circumstances, and even less so in a crisis.
\end{abstract}


This study aims to examine the extent of the structure and function of management control systems in pandemic conditions in Croatian organisations. An overview of current systems in organizations was given, as well as management challenges of the pandemic situations. This study includes the analysis of management control system during the pandemic times. The research was conducted using survey method what referred to analyses of strategic plans, performance evaluation systems, and management controls for performance evaluation in Croatian organisations. The factor analysis of the main components was conducted in order to examine the contribution of predictor variables in explaining the broad-scope management control system. In order to examine the contribution of gender, age, work experience, education, company size, aggregation, timeliness, and integration for explaining of broad-scope the management control system hierarchical regression analysis was conducted.

The results confirm that integration is significant predictor in the crisis controlling model, but at the same time, when the integration and timeliness should have positive connection, greater timeliness does not increase to the greater availability. This withdraws the conclusion that uncertainty of environment extents the speed of business processes. Despite of the equal integration during pandemic crises the remote working conditions caused the decrease of the promptness of reporting collected information, which requires new models of controlling in unpredictable situations.

Keywords: challenges, controlling, global changes, management control systems, pandemic

\section{INTRODUCTION}

Businesses today face many challenges. The implementation of new mechanisms and management modalities is necessary in order to identify threats, as well as opportunities, in a timely manner. The global crisis is pandemic crises caused by Covid-19 virus and it is according to the World Health Organization (WHO) a new and highly contagious disease. ${ }^{1}$ Coronavirus is a new virus discovered in 2019 that has not been known so far. ${ }^{2}$ The virus appeared in Wuhan, Hubei Province in China, but spread very rapidly to other parts of China and the rest of the world. ${ }^{3}$ The emergence of a pandemic is not only a blow to the health system, but also to the global economy. Since this is a new disease for which there was no cure at the time of its appearance, in many companies it brought changes to the way a certain business operates and disclosed the existing organizational problems. This

1 World Health Organizations. (2020). Coronavirus disease (COVID-19) outbreak situation. Retrieved from the World Health Organizations (WHO) Online: [https://www.who.int/ emergencies/diseases/ novel-coronavirus-2019], Accessed 13 April 2020.

2 World Health Organizations. (2020). Coronavirus disease (COVID-19) situation report - 83. Retrieved from the World Health Organizations (WHO) Online: [https://www.who.int/ emergencies/ diseases/novel-coronavirus-2019], Accessed 13 April 2020.

3 Zhu, N.; Zhang, D.; Wang, W.; Li, X.; Yang, B.; Song, J.; Zhao, X.; Huang, B.; Shi, W.; Lu, R.; Niu, P., A novel coronavirus from patients with pneumonia in China, 2019, New England Journal of Medicine, Vol. 382, 2020, pp. 727-733. 
crisis has revealed to us what lies beneath the surface of our organizations. Working from home, i.e. working remotely, has disturbed the balance between work and private life we have become accustomed to so far, and has become our new reality overnight. This way of working is nothing new, but Covid-19 has certainly accelerated the already growing trend that might even become permanent. The pandemic came on suddenly, and brings pressure on global business activities. ${ }^{4}$ The consequences of the crisis for business activities came as quickly as the virus itself, which spread around the world. Employee safety, cash flow, sales, and supply chains are just some of the issues that required a quick response. ${ }^{5}$ Covid-19 has amplified existing social inequalities and turned out to be a great revealer. ${ }^{6}$ This crisis is putting pressure on the business environment, and managers need to react quickly and make changes in their business operations. The best response in such situations is to turn to a higher level of controlling in organizations. The pandemic has put companies that turn to traditional models of management at a disadvantage. Managers who have a broader view of the management situation, which they gain with a higher level of controlling in the organization, make better decisions in complex situations. ${ }^{7},{ }^{8}$ With the increased amount of information, numbers and calculations that managers have at their disposal, they are able to make faster decisions that put the organization they lead in a situation where it can adapt to external influences and reduce uncertainty to a minimum. We conclude that controlling, regardless of the business environment, always plays an important role in management because it supports managers by providing them with the information necessary for quality decision making. Controlling is focused on the future by analyzing past and present events. Technological advances and globalization have greatly disadvantaged traditional business models and increased competitiveness. Controlling implies the overall business of an organization, and its parts represent strategic plans and analyses. It is perhaps the most important function in dealing with the organization's problems, and this department is directly responsible to management in informing them about the changes. Defining strategy, long-term

4 Spicer, A., Organizational Culture and COVID-19, Journal of Management Studies, Vol. 57, Issue 8, 2020, pp. 1737-1740.

5 Pantano, E.; Pizzi, G.; Scarpi, D.; Dennis, C., Competing during a pandemic? Retailers' ups and downs during the COVID-19 outbreak, Journal of Business Research, Vol. 116, 2020, pp. 209- 213.

6 Corak, M. 2020. COVID-19 is not the great leveller, it's the great revealer. Economics for Public Policy, April 13. [https://milescorak.com/2020/04/13/covid-19-is-not-the-great-leveller-its-thegreatrevealer/], Accessed 2 June 2021.

7 Jordao, R.V.D.; Souza, A.A.; Avelar, E.A., Organizational culture and post-acquisition changes in management control systems: An analysis of a successful Brazilian case, Journal of Business Research, Vol. 67, 2014, pp. 542-549.

$8 \quad$ Nielsen, L.B.; Mitchell, F.; Nørreklit, H., Management accounting and decision making: Two case studies of outsourcing, Accounting Forum, Vol. 39, Issue 1, 2015, pp. 66-82. 
sustainability and risk assessment are factors through which this process works. Growth, development and, ultimately, profit are the goal of every organization, and this is possible only if the aforementioned factors work successfully. MCS enhance the communication, learning and experimentation required for innovation in strategy formation. ' Some researches emphasize management control system (MCS) as a key to management innovation. ${ }^{10}$ Thus, a pandemic situation can demand unexpected innovative strategies and effort.

\section{THEORETICAL APPROACH TO RESEARCH}

Given that controlling is related to all management functions, it is difficult to define its activity. ${ }^{11}$ When talking about controlling, different definitions arise. Controlling represents multidisciplinary knowledge that for the purpose of quality decision-making gathers information inside and outside the organization, necessary for those in management positions. ${ }^{12}$ Common to all definitions of controlling is that it supports management in decision-making. The role of controlling is to connect all parts of the organization into a unified whole so as to create a comprehensive image of the company's business operations.

\subsection{Controlling functions}

The concept of controlling encompasses several functions: planning, control, and coordination. The planning function refers to determining future events, results and activity implementation. Future events represent possibilities for manoeuvre when it comes to activities. ${ }^{13}$ It is important for organizations to prepare in time for the upcoming changes. ${ }^{14}$ Execution is a key feature of management control. ${ }^{15}$ The control function compares two or more values to determine deviations from the plan that are viewed as control signals. The control function processes information that takes place at strictly defined time intervals, and is not always the last stage in management, but follows the creation processes from the very beginning. The informative function includes systematic collection, processing and making

9 Davila, T., The promise of management control systems for innovation and strategic change, in: Chapman, C.S. (ed.), Controlling strategy: Management, accounting, and performance measurement, New York, 2005, pp. 37-61.

10 Simons, R., Levers of Control, Harvard University Press, Boston, 1995, p. 5.

11 Očko, J.; Švigir, A., Kontroling-upravljanje iz backstagea, Knjiga print d.o.o., Zagreb, 2009.

12 Ibid.

13 Ziegenbein K., Kontroling, deveto prerađeno i aktualno izdanje, RRiF, Zagreb, 2008, p. 81.

14 Buble, M., Osnove menadžmenta, Ekonomski fakultet u Splitu, 2006, p. 86.

15 Merchant, K. A.; Van der Stede, W. A., Management control systems: performance measurement, evaluation and incentives, Pearson Education, 2017, p. 11. 
available of information important for the management of organizations. Organizations put a lot of effort into their information systems because without them, controllers would find it difficult to perform their tasks. ${ }^{16}$ The coordination function implies the harmonization of connected and separate processes. ${ }^{17}$ The aim of coordination is to provide support in creating a value system. The integration function makes all parts of the company meaningfully interdependent. All parts connect and form a whole.

\subsection{Concepts of controlling}

The development of controlling itself is influenced by various factors, so each country develops the concept of controlling in its own way. Social and economic development are one of the most important factors influencing this. The concept of control reaches far back in history and already in the 1960s, in France, controlling was present in over $50 \%$ of the most important companies. ${ }^{18}$ Controlling has evolved based on several concepts: the accounting-oriented concept, the information-oriented concept, and the management-oriented concept. The accountingoriented concept looks more to the future. Some of the features of the accounting concept are the preparation of accounting data and a quantity-oriented approach, while its goal is to ensure liquidity and profit. It also represents an instrument of the management. The second concept is information-oriented, and seeks to build its own information system of all users in the organization, that is to match the needs and supply of information, and thus make decisions. The managementoriented concept connects all functions in the organization for more successful business operations. According to the management-oriented concept, the original controlling functions are performed. This form of controlling represents harmonization in leadership, integration and coordination.

\section{DATA AND METHODOLOGY}

Earlier research, reports that tehnology or strategy of organization explains use of management control systems. Menagment control systems used by the organizations is affected by organizational life cycle, especially in growing organizations. Broad scope menagment control system (MCS) reduce negative affect of COVID 19 under the supposition that decision makers use that information. Bradth of calculations that decision makers have at his disposal with menagment control sys-

Očko; Švigir, op. cit., note 11, p. 35

Osmanagić Bedenik, N., Kontroling - Abeceda poslovnog uspjeha, Školska knjiga, Zagreb, 2007, p 104. Ibid. 
tem increase their chance for promptly movements in new situations, and decrease exposure to uncertainty.

This paper was based on previously validated constructs of the management control system provided by Chenhall and Morris (1986). ${ }^{19}$ The basis of their study was a combination of the company's features to measure a broad scope management control system design (MCS). The measure of broad-scope includes noneconomic information (customer preferences, employee attitudes, etc.), information about external factors (economic conditions), non-financial production data (output rates), and non-financial market data (market information).

The data for this paper was collected using the survey method. The analysis was made according to the experiences of working conditions in pandemic times due to the work effort, amount of work, level of difficulty, work productivity and quality. Sociodemographic data were also collected, such as gender, age, years of work experience, level of education. The survey included information about companies' characteristics, such as the type of work department in which participants are employed, the company size, and the companies type of business.

The data was collected using an online Google form. Via the snowball sampling method, a cross-sectional questionnaire was distributed. On average, the survey took about 10 minutes to complete. After collecting data statistical analysis were performed. Data analysis were conducted using Statistical Package for the Social Sciences (SPSS version 20.0, IBM, Chicago, IL, USA). The key statistical parameters and descriptive data were calculated. Factor analysis and reliability tests with Cronbach's alpha were conducted to examine the metric characteristics of measuring instruments. Hierarchical regression analysis (HRA) was conducted to examine the contribution of the predictor variables in explaining the broad-scope management control system.

The survey was conducted on a sample of 60 employees aged 21 to 57, with a mean age of 36.05 ( $\mathrm{SD}=8.08)$. Most of them have finished graduate study (51.7 $\%)$. Table 1 presents the sample structure.

19 Chenhall, R.H.; Morris, D., The impact of structure, environment, and interdependence on the perceived usefulness of management accounting systems, The Accounting Review, Vol. 61, Issue 1, 1986, pp. 16-35. 
Table 1. Sample structure $(\mathrm{N}=60)$

\begin{tabular}{|l|l|l|l|}
\hline & & $N$ & Percentage \\
\hline \multirow{3}{*}{ Gender } & Male & 39 & $65 \%$ \\
\cline { 2 - 4 } & Female & 21 & $35 \%$ \\
\hline \multirow{5}{*}{ Education } & Vocational high school & 2 & $3.3 \%$ \\
\cline { 2 - 4 } & Four-year high school & 10 & $16.7 \%$ \\
\cline { 2 - 4 } & Undergraduate study & 9 & $15 \%$ \\
\cline { 2 - 4 } & Graduate study & 31 & $51.7 \%$ \\
\cline { 2 - 4 } & Postgraduate study & 8 & $13.3 \%$ \\
\hline
\end{tabular}

Source: Authors' calculation

The respondents mostly work in a company with 11 and 50 employees $(35 \%)$, but also in larger companies, with more than 51 (25\%), and with more than 250 employees $(33.3 \%)$. The company size structure is presented in Figure 1. On average the respondents have almost 13 years of work experience $(\mathrm{M}=12.86$, $\mathrm{SD}=9.24)$.

Figure 1. Company size

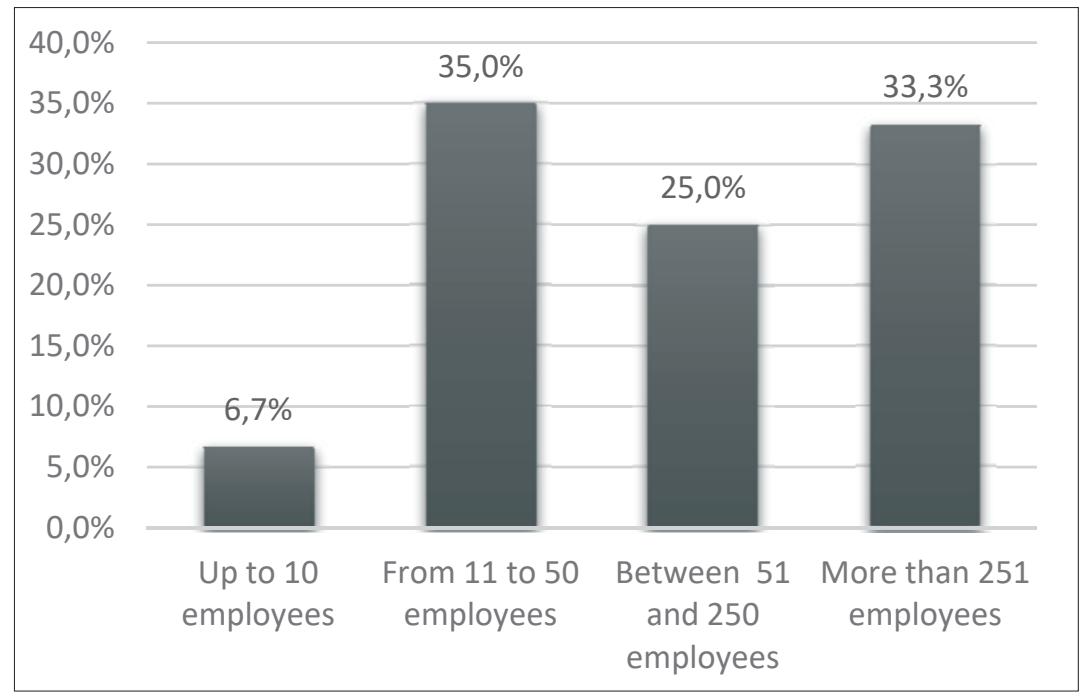

Source: Authors' calculation

Figure 2 presents the distribution of employees according to the department and agency (the type of company business). Most of them work in the finance, accounting, and controlling department (25\%), and in the sale department (16.7\%). 
Figure 2. Employees work department

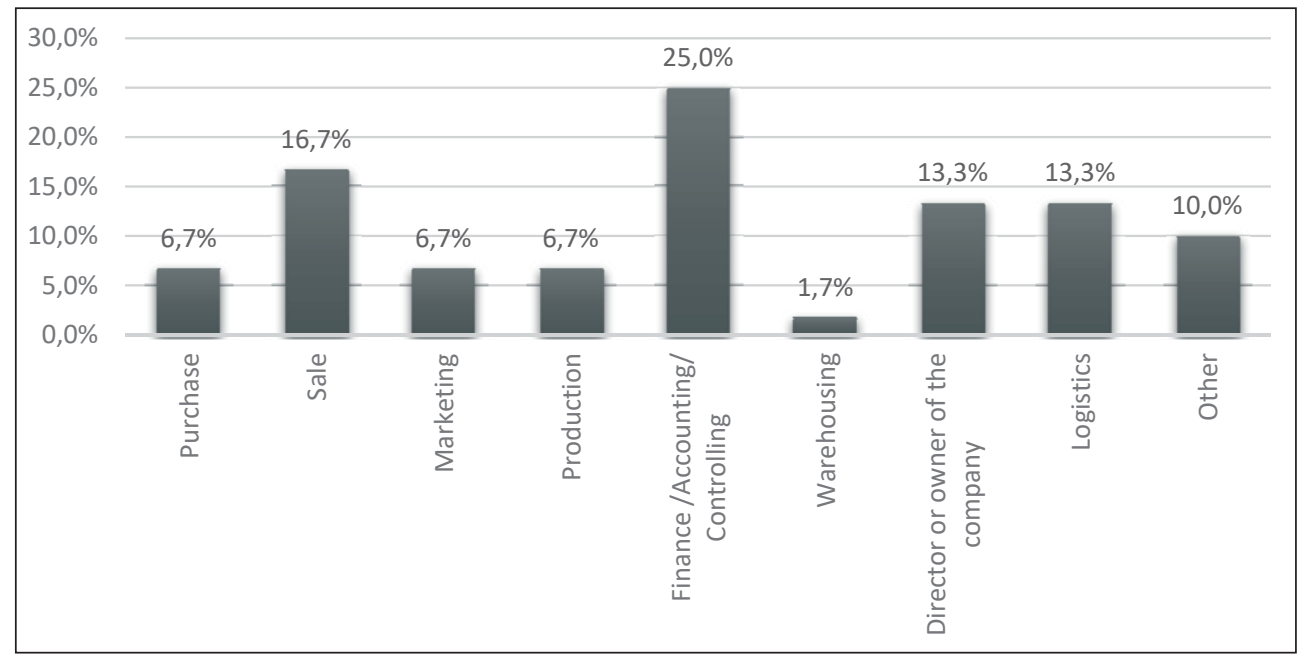

Source: Authors' calculation

Figure 3 shows the employees company agency. The company type of business of participants is mainly other supply/service agency $(38.3 \%)$, and trading $(20 \%)$.

Figure 3. Employees company agency

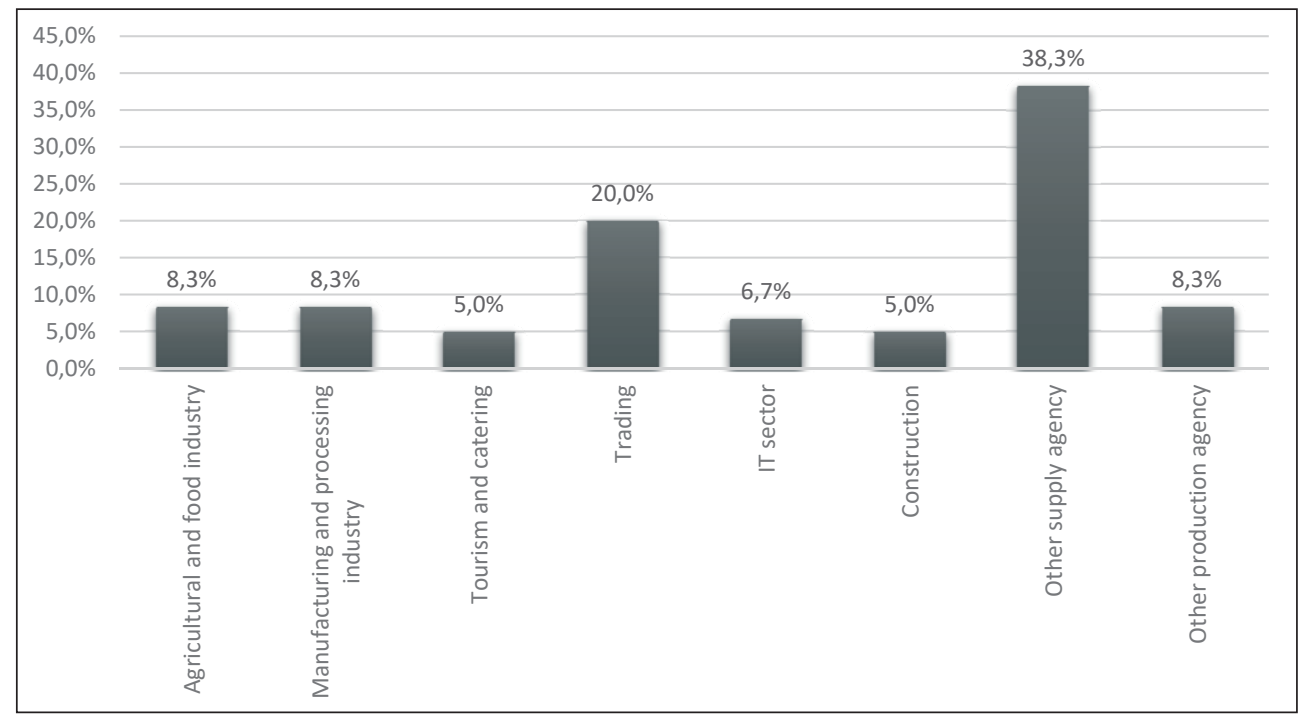

Source: Authors' calculation

After collecting data, the factor analysis was performed. The analysis showed a unidimensional measure that explains $77.16 \%$ of the variance (item factor load- 
ings are above 0.86 ). The reliability coefficient of Cronbach's alpha is 0.93 . In order to measure related constructs of a management control system, the availability of the following features was included: aggregation, timeliness, and integration. These features describe information characteristics that could be relevant for management control system design. ${ }^{20}$ Participants gave their self-assessment on the scale of Likert's type with seven levels of assessment (from 1 - not at all available, to 7 - available to a great extent). Feature of aggregation describes department reports and process of decision making, timeliness describes the frequency of reporting, and integration includes precise targets and company's performance. Internal reliability was examined, and Cronbach alpha reliability coefficients for aggregation, timeliness, and integration were high: 0.90, 0.90, and 0.93, respectively. Similar results of Cronbach's alpha were obtained in previous research. ${ }^{21}$

\section{RESULTS AND DISCUSSION}

Before conducting the factor analysis, the normality of the distributions was examined. The distributions of all measured variables are not significantly different from normal. This confirmed indexes of skewness and kurtosis. Absolute values of skewness are than 3 , and for kurtosis are less than 10 , which indicate that distributions are normal.

Table 2. Descriptive statistics

\begin{tabular}{|l|c|c|c|c|c|c|c|c|}
\hline & $\boldsymbol{k}$ & $\boldsymbol{M i n}$ & $\boldsymbol{M a x}$ & $\boldsymbol{M}$ & $\boldsymbol{S D}$ & $\boldsymbol{I}_{\boldsymbol{S}}$ & $\boldsymbol{I}_{\boldsymbol{K}}$ & $\boldsymbol{\alpha}$ \\
\hline Broad-scope MCS & 4 & 1.25 & 7.00 & 4.33 & 1.46 & .15 & -.57 & .93 \\
\hline Aggregation MCS & 3 & 1.00 & 7.00 & 4.41 & 1.61 & -.29 & -.24 & .90 \\
\hline Timeliness MCS & 3 & 1.00 & 7.00 & 4.33 & 1.62 & -.23 & -.60 & .90 \\
\hline Integration MCS & 3 & 1.00 & 7.00 & 4.53 & 1.59 & -.25 & -.58 & .93 \\
\hline
\end{tabular}

Legend: $\mathrm{k}$ - number of items; $\mathrm{I}_{\mathrm{S}}=$ skewness; $\mathrm{I}_{\mathrm{K}}=$ kurtosis; $\mathbb{\nabla}=$ Cronbach alpha reliability coefficient

Source: Authors' calculation

Table 2 presents the descriptive parameters and Cronbach alpha reliability coefficients for measured variables. Participants have assessed the availability of integration as the most available in their companies $(M=4.53, S D=1.59)$. Overall, it

20 Guenther, T.W.; Heinicke, A., Relationships among types of use, levels of sophistication, and organizational outcomes of performance measurement systems: The crucial role of design choices, Management Accounting Research, Vol. 42, 2019, pp. 1-25.

21 Spencer, S. Y.; Adams, C.; Yapa, P. W., The mediating effects of the adoption of an environmental information system on top management's commitment and environmental performance, Sustainability Accounting, Management and Policy Journal, Vol. 4 Issue 1, 2013, pp. 75-102. 
is evident that employees consider the measured features moderately available in their workplaces (all means are slightly above 4).

Hierarchical regression analysis was conducted in order to examine the contribution of gender, age, work experience, education, company size, aggregation, timeliness, and integration for explaining of broad-scope the management control system. Predictors of the proximal structure were introduced first, then predictors of distal structure. The conditions for using hierarchical regression analyses were first examined. The values of the Durbin-Watson test was 1.75 , which indicating that residuals are not intercorrelated. Values of variance inflation factor (VIF) are considerably below 10, and values of tolerance above 0.2 . Therefore, there is no multicollinearity. Intercorrelations between measured variables were also examined (Table 3).

Table 3. Interccorelations between predictors and criterion variable

\begin{tabular}{lccccccccc}
\hline & 1 & 2 & 3 & $\mathbf{4}$ & $\mathbf{5}$ & $\mathbf{6}$ & $\mathbf{7}$ & $\mathbf{8}$ & $\mathbf{9}$ \\
\hline 1. Gender & - & -.14 & -.15 & -.16 & -.03 & .01 & -.09 & -.03 & .10 \\
2. Age & & - & $.91^{* *}$ & $.31^{*}$ & .22 & -.20 & -.16 & -.13 & .22 \\
3. Work experience & & & - & $.26^{*}$ & .15 & -.28 & -.25 & -.23 & -.13 \\
4. Education & & & & - & .02 & -.05 & -.04 & -.06 & -.11 \\
5. Company size & & & & & - & -.12 & -.12 & -.08 & -.11 \\
6. Aggregation MCS & & & & & - & $.87^{* *}$ & $.89^{* *}$ & $.87^{* *}$ \\
7. Timeliness MCS & & & & & & - & $.87^{* *}$ & $.70^{* *}$ \\
8. Integration MCS & & & & & & & - & $.83^{* *}$ \\
9. Broad-scope MCS & & & & & & & & - \\
\hline
\end{tabular}

Note: ${ }^{* *} p<.01 ;{ }^{*} p<.05$

Source: Authors' calculation

Table 4. Hierarchical regression analysis for broad-scope MCS

\begin{tabular}{|l|c|c|}
\hline Predictors & 1. step & 2. step \\
\hline 1. Gender & .07 & .07 \\
\hline 2. Age & .15 & -.20 \\
\hline 3. Work experience & -.21 & $.34^{*}$ \\
\hline 4. Education & .09 & -.07 \\
\hline 5. Company size & -.11 & -.02 \\
\hline 6. Aggregation & & $.87^{* *}$ \\
\hline 7. Timeliness & & $-.41^{* *}$ \\
\hline 8. Integration & & $.46^{* *}$ \\
\hline$\Delta \mathrm{R}^{2}$ & .040 & .809 \\
\hline $\mathrm{R}^{2}$ & .040 & .849 \\
\hline $\mathrm{F}$ & .451 & $35.97^{* *}$ \\
\hline
\end{tabular}

Note: ${ }^{* *} p<.01 ;{ }^{*} p<.05$

Source: Authors' calculation 
After testing the conditions, a hierarchical regression analysis was conducted. In the first step of hierarchical regression analysis, gender, age, work experience, education, and company size were introduced. In the second step, the features of aggregation, timeliness, and integration were simultaneously introduced. Results of hierarchical regression analysis are shown in Table 4.

Predictor variables in the first step of hierarchical regression analysis were insignificant. However, results in the second step show that variables of work experience, aggregation, timeliness, and integration were statistically significant. Employees with more work experience estimate greater availability of non-economic information, information about external factors, and non-financial data about production and market. It can be assumed that employees with more years of work experience can recognise and identify this kind of information more successfully than those with less work experience. Those participants probably have greater authorise, so these forms of information are more accessible to them.

Aggregation is the most significant predictor of broad-scope management control system. The higher the capacity of a management control system to provide information in various forms is, the greater is the level of management control system design. Aggregation describes to what extent companies give data from various departments like time-aggregated information. Existing findings show that crisis could cause data overload or difficulties in decision-making. ${ }^{22}$ Research results show that in our companies there was no significant negative effect of the pandemic on the aggregation of information from the various functional area, as well as monthly and yearly reports and data analysis.

Results show that integration was also a significant predictor in this model. Stronger coordination between various departments and areas causes internal, external, financial, and non-financial information more available. Such information is related to a wide range of various content, like customer satisfaction, product trends and costs, employee needs to government policies. Same as for the aggregation, results show that there was no decrease in integration due to the pandemic crisis. The findings were according to the expectations, concerning the other studies that showed that integration is common action between departments in which they are following company goals. ${ }^{23}$ There are some ways to achieve differentiation, like rules and procedures. In the crisis time, there is a need for more differentia-

22 Garcia Osma, B.; Gomez-Conde, J.; Heras, E., Debt pressure and interactive use of control systems: Effects on cost of debt, Management Accounting Research, Issue 40, 2018, pp. 27-46.

23 Chenhall, R. H., Management control systems design within its organizational context: findings from contingency-based research and directions for the future, Accounting, organizations and society, Vol. 28, Issue 2-3, 2003, pp. 127-168. 
tion in order to face unknown situations, which can lead to integration problems. For such specific unpredictable situations, it is preferable to use some progressive mechanisms, like meetings and integrating employees, rather than a set of rules and procedures. Actions like this are a more organic type of structure and are more welcome in uncertain times.

One factor related to a broad-scope management control system is also frequency and promptness of reporting collected information, that is timeliness. According to some previous research, along with integration, the timeliness is becoming an increasingly important variable for management accounting data research. ${ }^{24}$ Usually, it would be expected that timely and aggregated information would lead to sustainable commitment for internal, external and non-financial data. However, in this research the relationship is different. Greater timeliness does not lead to a greater availability, on the contrary. These unexpected finding can be interpreted with limitations that have occurred due to the pandemic crisis. The unknown situation, such Covid crisis is unpredictable and surely have affected on promptness in collecting and submission various information and reports. When there is environmental uncertainty, companies face challenges, which is manifested to the greatest extent in speed processing generally in business.

Results show that the model in total explained almost $85 \%$ of the variance of a broad-scope management control system. Aggregation is the strongest predictor of a broad-scope management control system $(\mathbb{\Xi}=.87, p<.01)$. This is in accordance with previous research on the important role of MCS which facilitates managers to make more accurate decisions in uncertain times and crisis. ${ }^{25}$

In addition to this analysis, since the pandemic has appeared, in the period from March 2020, many people have started remote working. Since controlling involves the interaction of business processes that are subject to interpersonal relationships, the survey included some features and experiences about remote working at the time of the pandemic. Table 5 shows employees experiences from working at a distance from their homes.

24 Chenhall, R. H., Integrative strategic performance measurement systems, strategic alignment of manufacturing, learning and strategic outcomes: an exploratory study, Accounting, organizations and society, Vol. 30, Issue 5, 2005, pp. 395-422.

25 Gomez-Conde, J.; Malagueño, R.; Lopez-Valeiras, E.; Rosa, F.; Lunkes, R., The Effect of Management Control Systems in Managing the Unknown: Does the Market Appreciate the Breadth of Vision?, April 6, 2021, Available at SSRN: http://dx.doi.org/10.2139/ssrn.3675688. 
Table 5. Data about working conditions in pandemic times

\begin{tabular}{|c|c|c|c|c|c|c|c|c|c|c|c|c|}
\hline & $\mathrm{f}$ & $\%$ & $f$ & $\%$ & $f$ & $\%$ & $\mathrm{f}$ & $\%$ & $f$ & $\%$ & & \\
\hline & \multicolumn{2}{|c|}{ Much less } & \multicolumn{2}{|c|}{ Less } & \multicolumn{2}{|c|}{ Equally } & \multicolumn{2}{|c|}{ More } & \multicolumn{2}{|c|}{ Much more } & $\mathrm{M}$ & SD \\
\hline $\begin{array}{l}\text { The extent to } \\
\text { which people } \\
\text { invest effort when } \\
\text { working from } \\
\text { home }\end{array}$ & 2 & 3.3 & 11 & 18.3 & 16 & 26.7 & 23 & 38.3 & 8 & 13.3 & 3.40 & 1.05 \\
\hline \multirow{2}{*}{$\begin{array}{l}\text { Amount of work } \\
\text { when working } \\
\text { from home }\end{array}$} & 2 & 3.3 & 10 & 16.7 & 22 & 36.7 & 16 & 26.7 & 10 & 16.7 & 3.37 & 1.06 \\
\hline & \multicolumn{2}{|c|}{ Much harder } & \multicolumn{2}{|c|}{ Harder } & \multicolumn{2}{|c|}{ Equally } & \multicolumn{2}{|c|}{ Easier } & \multicolumn{2}{|c|}{$\begin{array}{l}\text { Much } \\
\text { easier }\end{array}$} & M & SD \\
\hline \multirow[t]{2}{*}{$\begin{array}{l}\text { Organising work } \\
\text { from home }\end{array}$} & 8 & 13.3 & 15 & 25 & 19 & 31.7 & 12 & 20 & 6 & 10 & 2.88 & 1.18 \\
\hline & \multicolumn{2}{|c|}{$\begin{array}{c}\text { Does not } \\
\text { compensate } \\
\text { at all }\end{array}$} & \multicolumn{2}{|c|}{$\begin{array}{c}\text { Does not } \\
\text { compensate }\end{array}$} & \multicolumn{2}{|c|}{$\begin{array}{l}\text { Partially } \\
\text { compensates }\end{array}$} & \multicolumn{2}{|c|}{$\begin{array}{c}\text { Compen- } \\
\text { sates }\end{array}$} & \multicolumn{2}{|c|}{$\begin{array}{l}\text { Fully com- } \\
\text { pensates }\end{array}$} & M & SD \\
\hline \multirow{2}{*}{$\begin{array}{l}\text { Cost recovery } \\
\text { (electricity, } \\
\text { internet) }\end{array}$} & 24 & 40 & 12 & 20 & 14 & 23.3 & 5 & 8.3 & 5 & 8.3 & 2.25 & 1.29 \\
\hline & \multicolumn{2}{|c|}{$\begin{array}{l}\text { Much more } \\
\text { insecure }\end{array}$} & \multicolumn{2}{|c|}{ Insecure } & \multicolumn{2}{|c|}{$\begin{array}{l}\text { Equally (in) } \\
\text { secure }\end{array}$} & \multicolumn{2}{|c|}{ Safer } & $\mathrm{Mu}$ & ch safer & $\mathrm{M}$ & SD \\
\hline \multirow[t]{2}{*}{$\begin{array}{l}\text { General experience } \\
\text { of job (in)security }\end{array}$} & 11 & 18.3 & 11 & 18.3 & 24 & 40 & 12 & 20 & 2 & 3.3 & 2.72 & 1.09 \\
\hline & \multicolumn{2}{|c|}{$\begin{array}{l}\text { Completely } \\
\text { disagree }\end{array}$} & \multicolumn{2}{|c|}{ Disagree } & \multicolumn{2}{|c|}{$\begin{array}{l}\text { Neither } \\
\text { agree nor } \\
\text { disagree }\end{array}$} & \multicolumn{2}{|c|}{ Agree } & \multicolumn{2}{|c|}{$\begin{array}{l}\text { Completely } \\
\text { agree }\end{array}$} & $\mathrm{M}$ & SD \\
\hline \multirow[t]{2}{*}{$\begin{array}{l}\text { Work from home } \\
\text { in the future }\end{array}$} & 4 & 6.7 & 4 & 6.7 & 18 & 30 & 20 & 33.3 & 14 & 23.3 & 3.60 & 1.12 \\
\hline & \multicolumn{2}{|c|}{ More worse } & \multicolumn{2}{|c|}{ Worse } & \multicolumn{2}{|c|}{ Equally } & \multicolumn{2}{|c|}{ Better } & \multicolumn{2}{|c|}{$\begin{array}{c}\text { Much bet- } \\
\text { ter }\end{array}$} & M & SD \\
\hline $\begin{array}{l}\text { Work productivity } \\
\text { when working } \\
\text { from home }\end{array}$ & 1 & 1.7 & 15 & 25 & 25 & 41.7 & 12 & 20 & 7 & 11.7 & 3.15 & 0.98 \\
\hline $\begin{array}{l}\text { Quality of online } \\
\text { meetings }\end{array}$ & 7 & 11.7 & 15 & 25 & 24 & 40 & 9 & 15 & 5 & 8.3 & 2.83 & 1.09 \\
\hline
\end{tabular}

Source: Authors' calculation

The emergence of the Covid pandemic have an impact on various aspects of human lives, and also on their characteristics of work. Generally, the aspects of work conditions have an important role within the companies and with the external 
environment. ${ }^{26}$ Since the pandemic occurred, the working population was forced to work from home due to strict guidelines to avoid physical contact. Such new instructions become a part of daily life in private, but also in office life.

Participants report to the greatest extent that they invest more effort $(38.3 \%)$ or the same amount of effort (26.7 \%) when working from home compared to work before the pandemic crisis. Employees have reported that they work equally (36.7 $\%)$ or more $(26.7 \%)$ when working from home. A quarter of the participants report that it is harder for them to organise work from home, and a third of them is the same in comparison to organising work before a pandemic. More than half of employees report that their companies do not compensate for their costs arising from work from home. Most participants perceive their job as equally secure or insecure as usually. The third of employees have stated that companies will strive to organise the work from home in the future also. Most of them $(41.7 \%)$ stated that the work productivity is the same as before pandemic situation, as well as the quality of online meetings in comparison with live meetings (40\%). In general, employees are least satisfied with the fact that their company does not compensate their costs when working from home.

These results will be used for the next research and the formation of an adequate model of management control system which will be designed according to the newly created working conditions.

\section{CONCLUSION}

The global pandemic crisis caused huge changes in every business process and forced companies to establish different business organizations. The management control systems had to adopt to the new environment and all concepts had to be redesigned according to the unexpected situation. The basic role of controlling refers to connecting all parts of the organization according to the constructs of a management control system. As the main constructors of controlling; aggregation, timeliness, and integration, were severely disturbed by the onset of the crisis, the analysis questioned the new settings and models in controlling should be defined. The starting point in the research was to define the main relationships that determine controlling model. The assessment was made by factor analysis. The analysis examined the availability of the aggregation, timeliness, and integration during pandemic times.

26 Parker, L. D.; Jeacle, I., The Construction of the Efficient Office: Scientific Management, Accountability, and the Neo-Liberal State, Contemporary Accounting Research, Vol. 36, Issue 3, 2019, pp. 1883-1926. 
The results show that stronger coordination between various departments and areas causes internal, external, financial, and non-financial information more available what makes the integration a significant element in the model even in the period of pandemic. The analysis of the second important feature, the timeline, confirmed that greater timeliness does not lead to a greater availability. The finding was contrary to the existing evidence and theory. The cause of the new postulate is connected to pandemic crisis and new organization of business process.

Although this research faced certain limitations, according to the relatively small sample and short observation period, the results are useful to the scientific and professional public, as well as to the management of various organizations, for designing new management control system.

This paper offers recommendations for further research, based on the results of remote working experiences at the time of the pandemic, concerning amount of working effort, organization of remote working, costs of working at home model, the work productivity and future trend predictions of working model.

\section{REFERENCES}

\section{BOOKS AND ARTICLES}

1. Buble, M., Osnove menadžmenta, Ekonomski fakultet u Splitu, 2006

2. Chenhall, R. H., Management control systems design within its organizational context: findings from contingency-based research and directions for the future, Accounting, organizations and society, Vol. 28, Issue 2-3, 2003, pp. 127-168

3. Chenhall, R. H., Integrative strategic performance measurement systems, strategic alignment of manufacturing, learning and strategic outcomes: an exploratory study, Accounting, organizations and society, Vol. 30, Issue 5, 2005, pp. 395-422

4. Chenhall, R.H.; Morris, D., The impact of structure, environment, and interdependence on the perceived usefulness of management accounting systems, The Accounting Review, Vol. 61, Issue 1, 1986, pp. 16-35

5. Davila, T., The promise of management control systems for innovation and strategic change, in: Chapman, C.S. (ed.), Controlling strategy: Management, accounting, and performance measurement, New York, 2005, pp. 37-61

6. Garcia Osma, B.; Gomez-Conde, J.; Heras, E., Debt pressure and interactive use of control systems: Effects on cost of debt, Management Accounting Research, Issue 40, 2018, pp. 27-46

7. Gomez-Conde, J.; Malagueño, R.; Lopez-Valeiras, E.; Rosa, F.; Lunkes, R., The Effect of Management Control Systems in Managing the Unknown: Does the Market Appreciate the Breadth of Vision?, Available at SSRN: [http://dx.doi.org/10.2139/ssrn.3675688]

8. Guenther, T.W.; Heinicke, A., Relationships among types of use, levels of sophistication, and organizational outcomes of performance measurement systems: The crucial role of design choices, Management Accounting Research, Vol. 42, 2019, pp. 1-25 
9. Jordao, R.V.D.; Souza, A.A.; Avelar, E.A., Organizational culture and post-acquisition changes in management control systems: An analysis of a successful Brazilian case, Journal of Business Research, Vol. 67, 2014, pp. 542-549

10. Merchant, K. A.; Van der Stede, W. A., Management control systems: performance measurement, evaluation and incentives, Pearson Education, 2017

11. Nielsen, L.B.; Mitchell, F.; Nørreklit, H., Management accounting and decision making: Two case studies of outsourcing, Accounting Forum, Vol. 39, Issue 1, 2015, pp. 66-82

12. Očko, J.; Švigir, A., Kontroling-upravljanje iz backstagea, Knjiga print d.o.o., Zagreb, 2009

13. Osmanagić Bedenik, N., Kontroling - Abeceda poslovnog uspjeha, Školska knjiga, Zagreb, 2007

14. Pantano, E.; Pizzi, G.; Scarpi, D.; Dennis, C., Competing during a pandemic? Retailers' ups and downs during the COVID-19 outbreak, Journal of Business Research, Vol. 116, 2020, pp. 209- 213

15. Parker, L. D.; Jeacle, I., The Construction of the Efficient Office: Scientific Management, Accountability, and the Neo-Liberal State, Contemporary Accounting Research, Vol. 36, Issue 3, 2019, pp. 1883-1926

16. Simons, R., Levers of Control, Harvard University Press, Boston, 1995

17. Spencer, S. Y.; Adams, C.; Yapa, P. W., The mediating effects of the adoption of an environmental information system on top management's commitment and environmental performance, Sustainability Accounting, Management and Policy Journal, Vol. 4 Issue 1, 2013, pp.75-102

18. Spicer, A., Organizational Culture and COVID-19, Journal of Management Studies, Vol. 57, Issue 8, 2020, pp. 1737-1740

19. Verma, S.; Gustafsson, A., Investigating the emerging COVID-19 research trends in the field of business and management: A bibliometric analysis approach, Journal of Business Research, Vol. 118, 2020, pp. 253-261

20. Zhu, N.; Zhang, D.; Wang, W.; Li, X.; Yang, B.; Song, J.; Zhao, X.; Huang, B.; Shi, W.; Lu, R.; Niu, P., A novel coronavirus from patients with pneumonia in China, 2019, New England Journal of Medicine, Vol. 382, 2020, pp. 727-733

21. Ziegenbein K., Kontroling, deveto prerađeno i aktualno izdanje, RRiF, Zagreb, 2008

\section{WEBSITE REFERENCES}

1. World Health Organizations (WHO), Coronavirus disease (COVID-19) outbreak situation, 2020, [https://www.who.int/emergencies/diseases/novel-coronavirus-2019?gclid= CjwKCAjwmv-DBhAMEiwA7xYrd2jEZnswwAWz2B1G8SPbkDylf0aRk BOOSM9Sx7uKZ00YMYjMLJ8ILRoCQrIQAvD_BwE],Accessed 13 April 2020

2. World Health Organizations (WHO), Coronavirus disease (COVID-19) situation report 83, 2020, [https://www.who.int/emergencies/diseases/novel-coronavirus-2019/situationreports], Accessed 13 April 2020

3. Corak, M. 2020. COVID-19 is not the great leveller, it's the great revealer. Economics for Public Policy, April 13, [https://milescorak.com/2020/04/13/covid-19-is-not-the-great-leveller-its-thegreat-revealer/], Accessed 2 June 2021 